Covered in: Web of Sciences (WOS); EBSCO; ERIH+; Google Scholar; Index Copernicus; Ideas RePeC; Econpapers; Socionet; CEEOL; Ulrich ProQuest; Cabell, Journalseek; Scipio; Philpapers; SHERPA/RoMEO repositories; KVK; WorldCat; CrossRef; CrossCheck

\section{Identifying the Students' Needs for Guidance at Vocational and Technical Anatolian High School}

\author{
Serdar ÖZMEN ${ }^{1}$, \\ Cigdem HURSEN²
}

${ }^{1}$ Near East University, Nicosia, Cyprus, serdarzmen@gmail.com

2 Assoc. Prof. Dr., Near East University, Nicosia, Cyprus, cigdem.hursen@neu.edu.tr
Abstract: The purpose of this study is to identify the needs of vocational and technical Anatolian high school students for guidance. A mixed research methodology is employed in this descriptive study. With the guidance needs analysis survey, quantitative data was collected about the needs of students for guidance from a total of 2228 participants including 1437 students, 304 teachers and 487 parents. The qualitative data in the research were collected from school counsellors employed in vocational and technical high schools, from the heads of guidance services employed in guidance research centres, from psychological guidance and counselling specialists working in the Ministry of National Education, from psychological counsellors representing Turkish Psychological Counselling and Guidance Association and those engaged by educational unions. The research revealed findings that the students need intensive guidance on topics such as identification of future career goals, learning effective studying methods, self-knowledge of interests and abilities, knowledge of professions and their basic requirements, focusing attention during lessons, protection from addiction, knowledge of developmental features of adolescence, university admission exams and opportunities for higher education. Furthermore, it was revealed that the guidance needs of the students were not met sufficiently, they needed services in all areas of personal-social, educational and career guidance, female students needed guidance services more than male students, and students felt more need of guidance services at higher grades. In line with the results of the study, further recommendations are presented to provide for the guidance needs of students.

Keywords: Comprehensive developmental guidance programmes; developmental guidance; guidance and psychological counselling; needs analysis; school guidance services.

How to cite: Özmen, S., \& Hursen, C. (2020).

Identifying the Students' Needs for Guidance at Vocational and Technical Anatolian High School.

Postmodern Openings, 11(4), 79-108.

doi:10.18662/po/11.4/224 


\section{Introduction}

It is a fact that globalisation is an irreversible phenomenon (Ivlampie, 2018) and rapid changes experienced in information societies in the post-modern era reshape our lives to a great extent (Martin, 2017). In this process, knowledge has gained more significance in all aspects of life and has become the only sustainable competitive element for individuals, organisations and nations (Bureš \& Otčenášková, 2018). The changes experienced in today's societies, which are defined as information societies, require individuals to gain a variety of skills such as adapting swiftly to developments, having a positive sense of self and self-confidence, building empathy development skills, and ensuring their internal motivation and selfcontrol (Altinay et al., 2020). Education is perceived as a key instrument for social change with regards to gaining these competencies (Karpov, 2019).

Although education is regarded as one of the most important instruments of social change, as a result of the rapid changes experienced in information societies (Martin, 2017) and technological developments (Bicen \& Demir, 2020), education itself is also subject to significant change (Korotkova et al., 2020). In information societies where 21 st century skills gain significance, taking the personal and social needs of students into account and reflecting the innovations on education that will increase the performance of teachers and students is an essential requirement (Hursen \& Beyoğlu, 2020). In line with the criticisms to the modern interpretation of education, the adoption of an understanding that places the student at the centre instead of the subject matter or the teacher is considered as one of the most important effects of post-modernism on education (Kesïi, 2019).

The understanding of education, which places the student at the centre, treats the individual holistically with his/her feelings, thoughts and values, and includes activities that support his/her development (Kuzgun, 2009). This understanding is based on the active participation of the students and their experiences in the education process (Demirel, 2013). Curricula are developed based on the interests and needs of the students (Mitchell, 2016). In this process, identifying the needs of students and studies to meet these needs are of critical importance. According to this understanding, educational activities do not only comprise of needs that are related to instruction. In education, student personality services aimed at supporting students' social, emotional, academic and career development as a whole, and within this scope, studies aimed at meeting the needs of 
students with regards to guidance and psychological counselling services, are included to a considerable extent (Yeşilyaprak, 2019). In line with the changing educational understanding, meeting the needs of students for guidance and psychological counselling services at sufficient levels is considered as one of the most important goals of education (Çetinkaya Yildız et al., 2018).

Today, the increase in social change, rapid dissemination of knowledge and socio-economic developments increase the needs of students for guidance services (Gysbers, 2001; Kuzgun, 2009; Negi, 2017; Prabu, 2015; Yeşilyaprak, 2019). Guidance refers to systematic and professional assistance to the individual in order for him/her to acquire the knowledge and skills necessary for the individual to develop in the most efficient way, to adapt to his/her environment, to set goals for the future and to make the right decisions (Tan, 1995). Guidance services offer a wide range of activities and programmes to enable the individual to realize himself/herself, his/her problems, the school environment and the world, to develop his/her capacity to make the right decisions, to discover himself/herself by exploring his/her interests, abilities and values (Kannammal, 2014). These services aim to support the development of a life career by acquiring the students with various qualifications in order to make them more functional in the present and in their future (Gysbers; 1997; Nazli, 2005).

Students need guidance services in personal-social, educational and career development areas (Campbell \& Dahir, 1997; Çetinkaya Yıldız et al., 2018; Güven, 2010; Gybers \& Henderson, 2012; Kaya \& Divitçi, 2002; Yeşilyaprak, 2019). The guidance needs of the students in the education process vary according to the developmental periods and environmental conditions (Kaya \& Divitçi, 2002; Myrick, 1989), and are met by personalsocial, educational and career guidance services (Ministry of National Education, 2017). Personal-social guidance aims for the student to understand and respect himself/herself and others and to develop effective interpersonal skills (Campbell \& Dahir, 1997), to consider himself/herself as a psycho-social being, to accept himself/herself, to make the best use his/her potential in these conditions by recognizing his/her physical and social environment with its actual dimensions (Yeşilyaprak, 2019). Educational guidance services aim for the student to be active in the learning process (Koruklu, 2010), to adapt the student to the school, to enable him/her make educational decisions in accordance with his/her characteristics, to make choices, to eliminate the factors that prevent success (Ilgar, 2002; Yüksel-Şahin, 2008) and to acquire him/her with knowledge, skills and attitudes to learn effectively (Campbell \& Dahir, 1997). Career 
guidance services aim to help students know themselves, realize their choices and help them make professional decisions in accordance with their characteristics (Çoban, 2010; Kannammal, 2014; Kuzgun, 2000). In order for school guidance services to be effective, the activities to be carried out should be arranged according to the needs of the students (Chireshe, 2012).

Vocational and technical Anatolian high schools within the Turkish education system are secondary education institutions delivering formal education for four years after secondary school, aiming to prepare students for higher education, their professions, life and professional fields through providing the students with a liberal education (Ministry of National Education, 2013). In secondary education institutions, educational, career and personal-social guidance services are conducted to prepare students for adulthood through evaluation of their individual characteristics and creation of a healthy identity to enable them to know their values and link these with social values, to assist them to be enthusiastic to attend higher education institutions, pursue fields that are suitable for them, to prepare them for professional life and obtain a profession (Ministry of National Education, 2017). From a developmental perspective, students at the secondary education level are considered to be in the adolescence period. According to Erikson (1994), this period is a process in which physical development accelerates, sexual motives are intense and there are various complexities related with the search for identity. The physical changes that take place, the diversification of social relations, the effort to create a system of values, the pursuit of a profession and the search for identity increase the need for guidance services (Ilgar, 2002). During the development process, guidance services are needed to enable the individual to know himself, to make choices for the future, to make decisions and to implement these decisions, to cope with the problems he/she faces, to realize his/her capacity by realizing his/her potential and to be able to realize himself/herself accordingly (Yeşilyaprak, 2019). The guidance needs of students arise at four different levels; developmental, preventive, remedial-corrective and crisisrelated (Gybers \& Henderson, 2012). It is of great importance to identify the guidance needs of students at all levels in schools and to develop guidance and counselling programmes to meet these needs.

Studies aimed at evaluating the needs play an important role in identifying which components will be included in the services to be provided, and also contribute to the redesign of the services. These studies provide data for identifying resources for improving service delivery and setting priorities for areas to be developed. This process may also reveal the 
need to develop action plans to fill the gaps between the current and the targeted situation (Tamir Tetroashvili \& Mezan 2020). To this end, various curricula can be developed in schools. Needs assessment studies serve to reveal the need for curriculum development and they are also an important part of the curriculum development process. Identifying the needs of students in education constitutes an important part of the curriculum development activities. Identification of the needs is important in the design of the educational activities (Demirel, 2013; Hanes, 1977; Oliva, 2005). The development of all kinds of curricula, including guidance and counselling programmes, requires the identification of students' needs (Erkan, 2017). The identification of the guidance needs of students forms the basis of guidance and counselling programmes (Güven, 2010; Gybers \& Henderson, 2012; Kaya \& Divitçi, 2002; Lapan, 2001). In the guidance and counselling programmes developed according to the developmental needs of the students (Campbell \& Dahir, 1997; MacDonald \& Sink, 1999), the needs analysis studies can be defined as a prerequisite for the determination of the overall objectives and scope of the programme (Nazli, 2014). Furthermore, the data obtained from the identification of the needs of the students can be used effectively during the programme evaluation process (Astramovich \& Coker, 2007; Wysong, 1983).

Research on the needs analysis of students reveals that there is a positive relationship between the features of the guidance and counselling services provided and the degree which the students' specific needs are defined (Astramovich, 2011). Therefore, it is important to identify whether there are differences in the guidance and counselling needs of students according to their grade levels and gender characteristics, and that guidance programmes are arranged to cover students' differentiated needs (Drefs, 2003; Gordon, 2000). The guidance and counselling programmes to be developed for this purpose may be differentiated within the scope of content, process and outcomes and class guidance services (Akos et al., 2007) as well as group size and demographic characteristics of students (Astramovich, 2011).

The success of school guidance and counselling programmes requires a common understanding, cooperation and participation. While school counsellors play a very important role in the development and implementation of the programme; the participation, cooperation and support of administrators, teachers, parents and other stakeholders in the community are crucial for the success of the programme (Gysbers, 1997). Particularly in the process of identifying the guidance needs of the students, it is recommended that not only the views of students but the views of 
different stakeholders are taken (Drefs, 2003; Gordon, 2000; Gybers \& Henderson, 2012). This will enable the adoption and ownership of the guidance and counselling programmes (Gordon, 2000; Robinson, 1999; Wysong, 1983). Thus, in this study, along with the views of students, the views of school counsellors, administrators, specialists, teachers, parents and representatives of various non-governmental organisations are taken to identify the students' need for guidance. The aim of the study is to determine the guidance needs of vocational and technical Anatolian high school students and to reach this aim, the answers to the following questions are sought:

1. What are the guidance needs of vocational and technical Anatolian high school students?

2. Do the students' needs for guidance differ according to the perceptions of students, school counsellors, parents and stakeholders?

3. Do the students' needs for guidance differ according to their sex?

4. Do the students' needs for guidance differ according to their grade levels?

5. Are the guidance needs of the students at the secondary education level sufficiently met?

\section{Methods}

This research is a descriptive study to identify the guidance needs of vocational and technical Anatolian high school students. The study employs a mixed research model in which qualitative and quantitative research methods are implemented. Thus, the strengths of qualitative and quantitative data (Büyüköztürk et al., 2012) were reflected in the research findings.

\subsection{Participants}

The study group of the research consists of two different groups; one from which the qualitative data is collected and the second one from which the quantitative data is collected. The study group from which the quantitative data is collected consists of students, students' parents and teachers from a total of 16 vocational and technical Anatolian high schools, 14 state and 2 private, in Ankara (Turkey). The information regarding the study group from which the quantitative data is collected is presented in Table 1. 
Identifying the Students' Needs for Guidance at Vocational and Technical ... Serdar ÖZMEN, Cigdem HURSEN

Table 1. Demographic Features of Participants for Quantitative Data Collection

\begin{tabular}{|c|c|c|c|c|}
\hline Participants & Variables & Categories & $\mathrm{N}$ & $\%$ \\
\hline \multirow{8}{*}{ Student } & \multirow{3}{*}{ Sex } & Female & 882 & 61,4 \\
\hline & & Male & 555 & 38,6 \\
\hline & & Total & 1437 & 100 \\
\hline & \multirow{5}{*}{ Grade } & 9th Grade & 445 & 31,0 \\
\hline & & 10th Grade & 410 & 28,5 \\
\hline & & 11th Grade & 306 & 21,3 \\
\hline & & 12th Grade & 276 & 19,2 \\
\hline & & Total & 1437 & 100 \\
\hline \multirow{7}{*}{ Teacher } & \multirow{3}{*}{ Sex } & Female & 228 & 75,0 \\
\hline & & Male & 76 & 25,0 \\
\hline & & Total & 304 & 100 \\
\hline & \multirow{4}{*}{ Branch } & Culture Courses Teacher & 203 & 66,8 \\
\hline & & Vocational Courses Teacher & 82 & 27,0 \\
\hline & & Administrator & 19 & 6,3 \\
\hline & & Total & 304 & 100 \\
\hline \multirow{3}{*}{ Parents } & \multirow{3}{*}{ Sex } & Female & 305 & 62,6 \\
\hline & & Male & 182 & 37,4 \\
\hline & & Total & 487 & 100 \\
\hline Grand Total & & & 2228 & 100 \\
\hline
\end{tabular}

Source: Authors' own conception

As presented in Table 1, it was aimed to reach a large number of people to obtain quantitative data about the guidance needs of the students. In this process, quantitative data was collected from a total of 2228 participants including 1437 students (64.5\%), 487 parents $(21.9 \%)$ and 304 teachers $(13.6 \%)$ with the help of the questionnaire form.

Qualitative data to determine the guidance needs of the students was collected with the interview form. In Table 2 the information on the stakeholders from whom the data is collected through the semi-structured interview form is presented. 
Table 2. Demographic Features of Participants for Qualitative Data Collection

\begin{tabular}{|c|c|c|c|}
\hline Variables & Categories & $\mathrm{N}$ & $\%$ \\
\hline \multirow{3}{*}{ Sex } & Female & 26 & 63,4 \\
\hline & Male & 15 & 36,6 \\
\hline & Total & 41 & 100,0 \\
\hline \multirow{8}{*}{ Duty } & $\begin{array}{l}\text { Vocational and Technical Secondary Education } \\
\text { Institution School Counselor }\end{array}$ & 24 & 58,5 \\
\hline & $\begin{array}{l}\text { Head of Department, Guidance and Research } \\
\text { Center }\end{array}$ & 8 & 19,5 \\
\hline & Psychological Counsellors in Ministry of National & & \\
\hline & Education Directorate General of Special & 4 & 9,8 \\
\hline & Education and Guidance Services & & \\
\hline & Representative of Education Union & 4 & 9,8 \\
\hline & $\begin{array}{l}\text { Board Member of Turkish Pyschlogical } \\
\text { Counselling and Guidance Association }\end{array}$ & 1 & 2,4 \\
\hline & Total & 41 & 100 \\
\hline \multirow{6}{*}{$\begin{array}{l}\text { Number of } \\
\text { Years in Service }\end{array}$} & $0-5$ years & 2 & 4,9 \\
\hline & $6-10$ years & 10 & 24,4 \\
\hline & $11-15$ years & 5 & 12,2 \\
\hline & $16-20$ years & 16 & 39 \\
\hline & 21 years and more & 8 & 19,5 \\
\hline & Total & 41 & 100 \\
\hline \multirow{7}{*}{ Graduation } & Guidance and Psychological Counselling & 22 & 53,6 \\
\hline & Psychology & 6 & 14,6 \\
\hline & Curriculum and Instruction & 7 & 17,1 \\
\hline & Educational Administration and Planning & 2 & 4,9 \\
\hline & Philosophy Education & 2 & 4,9 \\
\hline & Sociology & 2 & 4,9 \\
\hline & Total & 41 & 100 \\
\hline \multirow{6}{*}{ Degree } & Bachelor & 19 & 46,3 \\
\hline & Master Student & 7 & 17,1 \\
\hline & Master & 12 & 29,3 \\
\hline & Doctoral Student & 2 & 4,9 \\
\hline & Doctorate & 1 & 2,4 \\
\hline & Total & 41 & 100 \\
\hline \multirow{5}{*}{ Institution } & Vocational and Technical Anatolian High School & 23 & 56.1 \\
\hline & Guidance and Research Centre & 8 & 19.6 \\
\hline & Ministry of National Education Directorate & 4 & 9.8 \\
\hline & $\begin{array}{l}\text { General of Special Education and Guidance } \\
\text { Services }\end{array}$ & & \\
\hline & High School & 2 & 4.9 \\
\hline
\end{tabular}




$\begin{array}{lcc}\text { Anatolian Technical High School } & 1 & 2.4 \\ \text { Private Medical Vocational High School } & 1 & 2.4 \\ \text { Special Education Practice School } & 1 & 2.4 \\ \text { University } & 1 & 2.4 \\ \text { Total } & 41 & 100\end{array}$

\section{Source: Authors' own conception}

As presented in Table 2, the researchers aimed that the stakeholders from whom the qualitative data presents a comprehensive representation. For this purpose, qualitative data was collected with an interview form, from a total of 24 school counsellors working at vocational and technical Anatolian high schools, heads of department from 8 different guidance and research centres in Ankara (Turkey), 4 counsellors in Ministry of National Education Directorate General of Special Education and Guidance Services, counsellors from Turkish Psychological Counselling and Guidance Association and counsellors in four education unions which have more than ten thousand members.

\subsection{Data Collection Tool}

Within the scope of the research, in order to identify the needs of secondary education level students for guidance services, "Guidance Needs Analysis Survey Form" was developed by the researchers. The first step in the process of developing the survey forms was to review the learning outcomes in the existing secondary education guidance and counselling programme. Then, a national and international literature review was performed on school guidance services, developmental guidance, comprehensive guidance and counselling programmes. The relevant theses and articles about school guidance programmes in the National Theses Archive at the Council of Higher Education and the database of ULAKBIM (National Academic Network and Information Centre) in TUBITAK (The Scientific and Technological Research Council of Turkey) were analysed. Then, the international literature was reviewed. Particularly the ASCA (American School Counsellor Association) national model was analysed and the learning outcomes were reviewed. The studies about the guidance programmes abroad were examined the universal guidance needs of the students at this grade level were explored. In line with the data obtained from the literature review, a survey form consisting of 40 five-point Likerttype items and one open-ended question was formed. In order to ensure the content validity of the survey, expert opinions were asked from 15 faculty members from 6 different universities, particularly from academicians with 
academic studies on guidance and counselling programmes. Lawshe (1975) scope validity technique was employed to ensure the content validity of the scale. Every item in the survey form was evaluated according to its feature to determining students' guidance needs. To this end the experts' views for each item was collected and "Content Validity Ratio" (CVR) was calculated. In line with expert opinions, 6 item with a CVR value below 0,49 was excluded from the form and minor changes were made on 5 other items. As a result of the content validity studies, the content validity index of the questionnaire form, was calculated as 0.87 . At the end of this process, a 5point Likert-type questionnaire form consisting of 34 items (with three subdimensions; 17 items for personal-social guidance, 11 for educational guidance, 6 items for career guidance) and an open-ended question was formed. Within the scope of the pilot application, the survey form was administered to a total of 8 randomly selected secondary education level students, consisting of 2 students from each grade. Finally, two different versions of the form for teachers and parents were created based on the statements in the survey form for students.

In order to identify the needs of the students for guidance and psychological counselling services, "The Interview Form to Identify Students' Needs for Guidance" was developed by the researchers. In order to ensure the content validity of the semi-structured interview form, expert opinions were received from 12 faculty members working at the departments of Guidance and Psychological Counselling of 6 different universities (particularly from doctorate level academics with studies related to school guidance programmes). Furthermore, expert opinions were obtained from 2 faculty members from the department of curriculum and instruction and 1 from the department of assessment and evaluation. The qualitative data were collected from different levels of stakeholders (school counsellors, psychological counsellors at the guidance and research centre, experts from the Ministry of National Education, representatives of the education union and representatives of the Turkish Psychological Counselling and Guidance Association) to identify the guidance needs of students.

\subsection{Data Collection and Analysis}

Statistical analysis methods were employed to analyse the quantitative data obtained from the study. The quantitative data obtained were analysed using percentage, frequency and mean among descriptive statistical analysis methods. Primarily the collected data were analysed to determine whether the parametric tests could be performed or not for the purposes to identify if the guidance needs of the students differ according to 
their development areas, sex and grade levels. For this purpose, normality and homogeneity tests were performed. In this process, data set was organised by using missing value and outlier analysis and then measures of central tendency, mean deviation, coefficients of kurtosis and skewness were calculated and variance homogeneity test (Levene's Test) was performed. The reliability analysis of the survey form revealed the Cronbach Alpha reliability coefficient as .93 . In order to determine whether the differences in the guidance needs of the students were significant, independent-samples ttest and one-way ANOVA data analysis techniques were employed. The quantitative data obtained were summarised in the tables. Content analysis method was used for the analysis of the qualitative data. The qualitative data (audio recordings) obtained from the semi-structured interview form were transcribed, the data were coded by line-by-line, then the codes and themes were combined and themes and categories were formed through an inductive approach. The researchers confirmed with 4 participants whether the themes and categories formed reflected their statements or not. In this study, the reliability coefficient which is called internal consistency and conceptualized as the agreement between the coders (Miles \& Huberman, 2016) according to the Miles Huberman Model, was determined as .90. The frequencies of the themes stated as the students' needs for guidance are determined and the percentages of these frequencies are calculated. The qualitative data obtained are presented in tables and interpreted.

\section{Results}

\subsection{Findings Related to the Identifying the Students' Needs for Guidance at Vocational and Technical Anatolian High School}

Within the scope of the study, a mixed method was applied in order to determine the guidance needs of vocational and technical Anatolian high school students and necessary data were collected and analysed by using qualitative and quantitative data collection tools. Table 3 shows the mean of students, teachers and parents of the Guidance Needs Analysis Survey Form which is used to determine the guidance needs of the students. 
Table 3. The Means of Guidance Needs Analysis Survey Form for Students, Teachers and Parents

\begin{tabular}{lccc}
\hline Survey Form & $\mathrm{N}$ & $\begin{array}{c}\text { Mean } \\
(\mathrm{M})\end{array}$ & $\begin{array}{c}\text { Std. Deviation } \\
(\sigma)\end{array}$ \\
\hline Student & 1437 & 3,1568 &, 77751 \\
Teacher & 304 & 4,2255 &, 80573 \\
Parent & 487 & 3,3328 &, 84121 \\
Total & 2228 & 3,3411 &, 87250 \\
\hline
\end{tabular}

Source: Authors' own conception

Table 3 reveals that the students need an intensive level of guidance services $(M=3.34)$ and it is the teachers who expressed the guidance needs of their students the most $(\mathrm{M}=4.22)$.

In the Guidance Needs Analysis Survey Form, the students have expressed most frequently that they need guidance services for obtaining information about the university admission exams $(M=3,88, \sigma=1,29)$, learning effective studying methods $(M=3,66, \sigma=1,26)$, learning how to focus attention during lessons $(\mathrm{M}=3,54, \sigma=1,533)$, determining careerrelated goals $(\mathrm{M}=3,54, \sigma=1,39)$, learning about professions that are appropriate for their personal characteristics $(\mathrm{M}=3,52, \sigma=1,28))$ and learning about opportunities for higher education $(\mathrm{M}=3.52, \sigma=1.37)$. Furthermore, in the answer to the open-ended question included in the survey, the students expressed their needs for guidance as learning effective studying methods $(\mathrm{N}=147)$, anger management $(\mathrm{N}=110)$, inter-family communication $(\mathrm{N}=85)$, healthy communication with friends $(\mathrm{N}=42)$, gaining self-confidence $(\mathrm{N}=39)$, goal setting $(\mathrm{N}=32)$, motivation $(\mathrm{N}=$ 30 ), ability to cope with peer bullying $(\mathrm{N}=18)$, ability to develop decisionmaking $(\mathrm{N}=18)$, self-knowledge $(\mathrm{N}=17)$, using time efficiently $(\mathrm{N}=17)$, coping with exam anxiety $(\mathrm{N}=15)$ and obtaining information about university exams $(\mathrm{N}=15)$.

The teachers stated that the students need guidance mostly on effective studying methods ( $\mathrm{M}=4.47, \sigma=1.05)$, protection from the negative effects of technology addiction $(\mathrm{M}=4.47, \sigma=1.01)$, focusing attention during lessons $(\mathrm{M}=4,45, \sigma=, 98)$, having information about safe internet use $(\mathrm{M}=4.42, \sigma=98)$, determining future goals related to education $(M=4.41, \sigma=1.02)$, anger management $(M=4,41, \sigma=1,01)$ and effective time management $(\mathrm{M}=4,40, \sigma=98)$. In addition, in the answer to 
the open-ended questions included in the survey, the teachers expressed that their students need guidance mostly on communication skills $(\mathrm{N}=45)$, obtaining information about university admission exams $(\mathrm{N}=32)$, developing healthy living-hygiene and self-care skills $(\mathrm{N}=25)$, motivation $(\mathrm{N}=23$ ), time management $(\mathrm{N}=20$ ), safe internet use (effective and positive use of social media) $(\mathrm{N}=20)$ and protection from technology addiction $(\mathrm{N}=17)$.

The parents of the students stated that their children need guidance mostly on obtaining information on university exams $(\mathrm{M}=4,21, \sigma=1,27)$, learning effective studying methods $(\mathrm{M}=3,96, \sigma=1,30)$, focusing attention during lessons $(M=3,91, \sigma=1,30)$, learning about opportunities for higher education ( $M=3,76, \sigma=1,25)$, determining career-related goals $(M=3,73$, $\sigma=1,39)$ and recognising their professional values $(\mathrm{M}=3.69, \sigma=1.34)$. Furthermore, in the answers to the open-ended question the parents of the students expressed that their children need guidance mostly on developing healthy communication $(\mathrm{N}=27)$ and effective friendship relationships $(\mathrm{N}=$ 18), gaining self-confidence $(\mathrm{N}=15)$, goal setting $(\mathrm{N}=15)$, anger management, $(\mathrm{N}=14)$ knowledge of professions $(\mathrm{N}=12)$ and protection from technology addiction $(\mathrm{N}=12)$.

Table 4 presents the results of the qualitative data obtained from face to face interviews to explore the needs of students for guidance with school counsellors, heads of department of guidance and research centers, Specialists of Ministry of National Education and representatives of Turkish Psychological Counselling and Guidance Association.

Table 4. Distribution of Guidance Needs for Development Areas According to Stakeholder Views

\begin{tabular}{llcc}
\hline \multirow{2}{*}{ Themes } & \multicolumn{1}{c}{ Categories (Guidance Needs) } & \multicolumn{2}{c}{$\begin{array}{c}\text { FrequencyPercentage } \\
(\%)\end{array}$} \\
\hline & $\begin{array}{l}\text { Developing effective communication skills } \\
\text { Protection from negative effects of }\end{array}$ & 39 & 9,15 \\
& $\begin{array}{l}\text { technology addiction, safe use of social } \\
\text { media }\end{array}$ & 33 & 7,75 \\
Personal-Social & $\begin{array}{l}\text { Knowledge of developmental features of } \\
\text { Guidance }\end{array}$ & 21 & 4,93 \\
& $\begin{array}{l}\text { adolescence period } \\
\text { Gaining self-confidence }\end{array}$ & 18 & 4,23 \\
& $\begin{array}{l}\text { Acquiring self-expression skills } \\
\text { Protection from addictive substances }\end{array}$ & 18 & 4,23 \\
& & 15 & 3,52
\end{tabular}


Coping with peer pressure $\quad 12$

2,82

Anger management

Acquiring self-esteem

Acquiring skills to say no when necessary

Acquiring skills for effective conflict resolution

Acquiring skills to cope with emotional problems of adolescence

Safeguarding from negligence and abuse

Acquiring skills to ask for help and receive help

Acquiring skills for effective problemsolving

Acquiring skills of assertiveness

Awareness of gender discrimination

Developing respect for differences

Awareness of individual rights and

responsibilities

9

8

6

1,

Recognising emotions and acquiring effective emotion management skills

Acquiring sense of responsibility 5

1,17

$4 \quad 0,94$

$4 \quad 0,94$

$3 \quad 0,70$

$3 \quad 0,70$

Total

Knowledge of effective studying methods

Determining future goals on education

School adaptation (orientation)

Acquiring time management skills

Acquiring motivation

Educational

Guidance

Knowledge of opportunities for higher

education

Coping with exam anxiety

Focusing attention during lessons

Gaining academic self-confidence

Recognising learning style

3

0,70

$2 \quad 0,47$

255

59,9

25

5,87

$19 \quad 4,46$

$14 \quad 3,29$

$12 \quad 2,82$

$8 \quad 1,88$

Total

Recognising professions

$5 \quad 1,17$

Self-knowledge of interests, abilities and values

\begin{tabular}{lcc} 
Total & 95 & 22,3 \\
\hline Recognising professions & 29 & 6,81 \\
Self-knowledge of interests, abilities and & 25 & 5,87 \\
values & 9 & 2,11 \\
Setting career-related goals & 8 & 1,88 \\
Developing decision-making skills & 3 & 0,70 \\
Avoiding prejudice for professions & 2 & 0,47 \\
Knowledge of occupational health and & &
\end{tabular}




$$
\begin{array}{ccc} 
& 76 & 17,8 \\
\text { Grand Total } & 426 & 100
\end{array}
$$

\section{Source: Authors' own conception}

Table 4 reveals that the stakeholders stated that the students need guidance mostly on communication skills $(\mathrm{f}=39)$, information about professions $(\mathrm{f}=29)$, methods of effective studying $(\mathrm{f}=25)$, self-knowledge of interest, ability and values $(f=25)$, developmental features of adolescence $(\mathrm{f}=21)$, determining future goals on education $(\mathrm{f}=19)$, self-expression skills $(\mathrm{f}=18)$, gaining self-confidence $(\mathrm{f}=18)$ use of technology $(\mathrm{f}=33)$, recognition of professions ( $\mathrm{f}=29)$, efficient teaching techniques $(\mathrm{f}=25)$, selfinterests, abilities and values $(\mathrm{f}=25)$, developmental characteristics of adolescence $(\mathrm{f}=21)$, determining future goals related to education $(\mathrm{f}=19)$, self-expression skills $(\mathrm{f}=18)$ and self-confidence $(\mathrm{f}=18)$ and protection from addictive substances ( $\mathrm{f}=15$ ).

\subsection{Findings Related to the Perceptions of Student, Teachers, Parents and Stakeholders Regarding the Students' Needs for Guidance}

One-way ANOVA results conducted to determine whether students' needs for educational, career and personal-social guidance needs differ according to the perceptions of students, teachers and parents are presented in Table 5 .

\begin{tabular}{|c|c|c|c|c|c|c|c|c|}
\hline \multicolumn{2}{|c|}{ Groups } & $\begin{array}{c}\begin{array}{c}\text { Source } \\
\text { of } \\
\text { Variance }\end{array} \\
\end{array}$ & \multirow{2}{*}{$\begin{array}{l}\begin{array}{l}\text { Sum of } \\
\text { Squares }\end{array} \\
187,398\end{array}$} & df & $\begin{array}{l}\text { Mean } \\
\text { Square }\end{array}$ & $\mathrm{F}$ & $\mathrm{p}$ & Significance \\
\hline \multirow{4}{*}{ 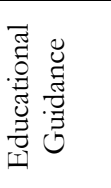 } & & Retween & & 2 & 03609 & 133949 & \multirow{4}{*}{, 000 } & \multirow{4}{*}{$\begin{array}{l}1-2,1-3 \\
2-3\end{array}$} \\
\hline & 2.Teacher & Groups & & & & (1) & & \\
\hline & \multirow[t]{2}{*}{ 3.Parent } & $\begin{array}{l}\text { Within } \\
\text { Groups }\end{array}$ & 1556,417 & 2225 & (700 & & & \\
\hline & & Total & 1743,816 & 2227 & & & & \\
\hline \multirow{3}{*}{ 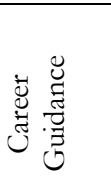 } & \multirow{3}{*}{$\begin{array}{l}\text { 1.Student } \\
\text { 2.Teacher } \\
\text { 3.Parent }\end{array}$} & $\begin{array}{l}\text { Between } \\
\text { Groups }\end{array}$ & 187,658 & 2 & 93,829 & \multirow[t]{3}{*}{104,702} & \multirow[t]{3}{*}{, 000} & \multirow[t]{3}{*}{$\begin{array}{l}1-2,1-3 \\
2-3\end{array}$} \\
\hline & & $\begin{array}{l}\text { Within } \\
\text { Groups }\end{array}$ & 1993,936 & 2225 & \multirow[t]{2}{*}{,896 } & & & \\
\hline & & Total & 2181,594 & 2227 & & & & \\
\hline \multirow{3}{*}{ 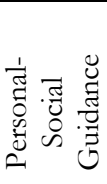 } & $\begin{array}{l}\text { 1.Student } \\
\text { 2.Teacher }\end{array}$ & $\begin{array}{l}\text { Between } \\
\text { Groups }\end{array}$ & 425,958 & 2 & 212,979 & 277,485 & \multirow[t]{3}{*}{,000 } & \multirow[t]{3}{*}{$\begin{array}{l}1-2,1-3 \\
2-3\end{array}$} \\
\hline & 3.Parent & $\begin{array}{l}\text { Within } \\
\text { Groups }\end{array}$ & 1707,762 & 2225 & \multirow[t]{2}{*}{,768 } & & & \\
\hline & & Total & 2133,721 & 2227 & & & & \\
\hline
\end{tabular}

Table 5. One-Way ANOVA Results Regarding the Perceptions of Students, Teachers and Parents for Students' Guidance Needs

Source: Authors' own conception 
As a result of the one-way analysis of variance, it is revealed that there are significant differences in the perceptions of students, teachers and parents regarding the guidance needs of the students. It is revealed that there are significant differences between the perceptions of students, teachers and parents in the educational, career and personal-social guidance areas and there are significant differences between the perceptions of teachers and parents. Teachers, more than students and parents, stated that students have needs for guidance. Parents, more than the students, stated they their children have guidance needs. The distribution of guidance needs of students according to the development areas that are collected through needs analysis survey forms are presented in Table 6.

Table 6. Distribution of Guidance Needs According to Development Areas

\begin{tabular}{llcc}
\hline Participants & Development Areas & Mean $(\mathrm{M})$ & Std. Dev. $(\sigma)$ \\
\hline \multirow{4}{*}{ Student } & Educational Guidance & 3,3421 &, 82934 \\
& Career Guidance & 3,3726 &, 95968 \\
& Personal Social Guidance & 2,9350 &, 85994 \\
& Total & 3,1568 &, 77751 \\
\hline \multirow{4}{*}{ Teacher } & Educational Guidance & 4,2023 &, 83971 \\
& Career Guidance & 4,2373 &, 84727 \\
& Personal Social Guidance & 4,2348 &, 83342 \\
\multirow{5}{*}{ Parent } & Total & 4,2255 &, 80573 \\
& Educational Guidance & 3,5600 &, 85477 \\
& Career Guidance & 3,5339 &, 96640 \\
& Personal Social Guidance & 3,0886 &, 94649 \\
& Total & 3,3328 &, 84121 \\
\hline
\end{tabular}

Source: Authors' own conception

Table 6 reveals that development area for which the students feel the most need is career guidance $(\mathrm{M}=3.37, \sigma=, 959)$ and needs for educational guidance services follows this area with a close rate $(M=3,34, \sigma=, 829)$. Students stated that they need personal-social guidance the least $(M=2,93$, $\sigma=859)$. Although the rates are close to each other, the teachers stated that the students need guidance the most for personal-social guidance $(M=4.23$, $\sigma=, 833)$ and career guidance $(\mathrm{M}=4.23, \sigma=, 847)$. Teachers stated that the least need for guidance for their students is educational guidance $(M=4,20$, $\sigma=, 839)$. The parents of the students stated that their children need educational guidance the most $(\mathrm{M}=3,56, \sigma=854)$ and personal-social guidance, the least $(M=3,08, \sigma=, 946)$. Briefly, according to Table 6 , the 
students highlighted the needs related to career guidance, parents highlighted the needs related to educational guidance and teachers underlined the needs related to personal-social guidance.

The distribution according to development areas of the qualitative data collected from the stakeholders with the interview form is presented in Table 7.

Table 7. The Distribution of Guidance Needs Related to the Development Areas According to the Perceptions of Stakeholders

\begin{tabular}{lcc}
\hline Development Areas & $\begin{array}{c}\text { Frequency } \\
(\mathrm{f})\end{array}$ & $\begin{array}{c}\text { Percentage } \\
(\%)\end{array}$ \\
\hline Personal Social Guidance & 255 & 59.9 \\
Educational Guidance & 95 & 22.3 \\
Career Guidance & 76 & 17.8 \\
Total & 426 & 100 \\
\hline
\end{tabular}

Source: Authors' own conception

According to Table 7, the stakeholders believe that the students need guidance the most on personal-social guidance (\%59.9). The stakeholders believe that the needs of students for guidance on the area of educational guidance $(22.3 \%)$ are more than their needs on the area of career guidance $(17.8 \%)$.

\subsection{Findings Regarding the Relationship between the Students' Needs for Guidance and Sex Variable}

The results of independent samples t-test performed to identify whether the guidance needs of students differ according to their sex are presented in Table 8.

Table 8. The Distribution of Independent Samples T-Test Results of Students' Guidance Needs According to Their Sex

\begin{tabular}{|c|c|c|c|c|c|c|c|}
\hline Items & Groups & $\mathrm{N}$ & $\begin{array}{c}\text { Mean } \\
(\mathrm{M})\end{array}$ & $\begin{array}{c}\text { Std. } \\
\text { Dev. } \\
(\sigma)\end{array}$ & $\mathrm{df}$ & $\mathrm{t}$ & $\mathrm{p}$ \\
\hline Educational Guidance & $\begin{array}{l}\text { Female } \\
\text { Male }\end{array}$ & $\begin{array}{l}882 \\
555\end{array}$ & $\begin{array}{l}3,3981 \\
3,2532\end{array}$ & $\begin{array}{l}80725 \\
, 85652\end{array}$ & 1435 & 3,234 & ,001 \\
\hline Career Guidance & $\begin{array}{l}\text { Female } \\
\text { Male }\end{array}$ & $\begin{array}{l}882 \\
555\end{array}$ & $\begin{array}{l}3,4752 \\
3,2889\end{array}$ & $\begin{array}{l}99344 \\
98531\end{array}$ & 1435 & 3,473 & ,001 \\
\hline Personal & 1 Female & 882 & 3,0080 & ,84959 & 1435 & 3,273 & 001 \\
\hline
\end{tabular}




\begin{tabular}{llllllll} 
Guidance & Male & 555 & 2,8577 &, 84430 & & & \\
\multirow{2}{*}{ Total } & Female & 882 & 3,2166 &, 77303 & \multirow{2}{*}{1174} & \multirow{2}{*}{3,690} & \multirow{2}{*}{, 000} \\
\hline
\end{tabular}

Source: Authors' own conception

Table 8 reveals that the needs of students for guidance differ significantly according to sex variable. In general, female students need guidance services more than male students. It can be stated that in all the educational, career and personal-social development areas, female students' guidance needs are more than those of male students. Moreover, it can be stated that the needs of female and male students for guidance display a significant difference and female students need guidance services more than male students on the subjects of effective studying methods $(t=3,113, p$ $<0.05)$, effective time management $(\mathrm{t}=4,321, \mathrm{p}<0.05)$, decision making $(\mathrm{t}$ $=4,175, \mathrm{p}<0.05)$, exam anxiety $(\mathrm{t}=3,386, \mathrm{p}<0.05)$, self-knowledge of abilities $(\mathrm{t}=2,279, \mathrm{p}<0.05)$, learning their professional values $(\mathrm{t}=3,562, \mathrm{p}$ $<0.05$ ), having information about the sources that promote professions $(\mathrm{t}=3,895, \mathrm{p}<0.05)$, having information about university admission exams $(\mathrm{t}=4,405, \mathrm{p}<0.05)$, setting future-oriented education goals $(\mathrm{t}=3,144, \mathrm{p}$ $<0.05)$, setting future-oriented career goals $(t=3,204, \mathrm{p}<0.05)$, acquiring effective problem-solving skills $(\mathrm{t}=3,204, \mathrm{p}<0.05) \mathrm{t}=2,657, \mathrm{p}<0.05)$, safeguarding against the negative effects of technology addiction $(\mathrm{t}=2,180, \mathrm{p}$ $<0.05)$, defending their rights by appropriate means $(\mathrm{t}=2,954, \mathrm{p}<0.05)$, coping with peer pressure $(t=3,317, p<0.05)$, coping with stress $(t=4,800$, $\mathrm{p}<0.05)$ and being informed about safeguarding from negligence and abuse $(\mathrm{t}=5,982, \mathrm{p}<0.05)$. It can be stated that only the need for healthy communication with the opposite sex differs according to sex $(t=-1,986$, $\mathrm{p}<0.05)$ and that the male students feel more need on this subject.

\subsection{Findings Regarding the Relationship between the Students' Needs for Guidance and Grade Levels}

The results of one-way ANOVA performed to identify whether the guidance needs of students differ according to their grade levels are presented in Table 9. 
Identifying the Students' Needs for Guidance at Vocational and Technical ... Serdar ÖZMEN, Cigdem HURSEN

Table 9.The Distribution of One-Way ANOVA Results of Students' Guidance Needs According to Their Grade Levels

\begin{tabular}{|c|c|c|c|c|c|c|c|c|}
\hline & Groups & $\begin{array}{l}\text { Source of } \\
\text { Variance }\end{array}$ & $\begin{array}{l}\text { Sum of } \\
\text { Squares }\end{array}$ & df & $\begin{array}{l}\text { Mean } \\
\text { Square }\end{array}$ & $\mathrm{F}$ & $\mathrm{p}$ & Significance \\
\hline \multirow{5}{*}{ 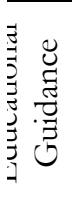 } & \multirow{5}{*}{$\begin{array}{l}9^{\text {th }} \text { Grade } \\
10^{\text {th }} \text { Grade } \\
11^{\text {th }} \text { Grade } \\
12^{\text {th }} \text { Grade }\end{array}$} & Between & 10,100 & 3 & \multirow[t]{2}{*}{3,367} & \multirow[t]{5}{*}{4.935} & \multirow[t]{5}{*}{, 002} & \multirow{5}{*}{$\begin{array}{l}9-10,9-11, \\
9-12\end{array}$} \\
\hline & & Groups & & & & & & \\
\hline & & Within & 977,583 & 1433 & \multirow[t]{3}{*}{,682 } & & & \\
\hline & & Groups & & & & & & \\
\hline & & Total & 987,682 & 1436 & & & & \\
\hline \multirow{5}{*}{ 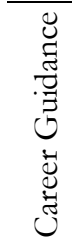 } & \multirow{5}{*}{$\begin{array}{l}9^{\text {th }} \text { Grade } \\
10^{\text {th }} \text { Grade } \\
11^{\text {th }} \text { Grade } \\
12^{\text {th }} \text { Grade }\end{array}$} & Between & 8,195 & 3 & \multirow[t]{5}{*}{2,732} & 2.774 & \multirow[t]{5}{*}{,040 } & \multirow[t]{5}{*}{$9-11,9-12$} \\
\hline & & Groups & & & & & & \\
\hline & & Within & 1410,971 & 1433 & & & & \\
\hline & & Groups & & & & & & \\
\hline & & Total & 1419,166 & 1436 & & & & \\
\hline \multirow{5}{*}{ 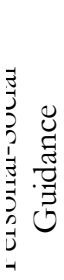 } & \multirow{5}{*}{$\begin{array}{l}9^{\text {th }} \text { Grade } \\
10^{\text {th }} \text { Grade } \\
11^{\text {th }} \text { Grade } \\
12^{\text {th }} \text { Grade }\end{array}$} & Between & 9,594 & 3 & \multirow[t]{2}{*}{3,198} & 4.454 & \multirow[t]{5}{*}{, 004} & \multirow{5}{*}{$\begin{array}{l}9-11,9-12, \\
10-11, \\
10-12\end{array}$} \\
\hline & & Groups & & & & & & \\
\hline & & Within & 1028,929 & 1433 & \multirow[t]{3}{*}{,718 } & & & \\
\hline & & Groups & & & & & & \\
\hline & & & $1050,5<4$ & 1450 & & & & \\
\hline \multirow{5}{*}{ 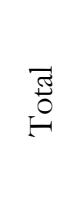 } & $9^{\text {th }}$ Grade & Between & 8,292 & 3 & \multirow[t]{5}{*}{2,764} & 4.606 & \multirow[t]{5}{*}{,003 } & \multirow[t]{5}{*}{$9-11,9-12$} \\
\hline & $10^{\text {th }}$ Grade & Groups & & & & & & \\
\hline & $11^{\text {th }}$ Grade & Within & 859,799 & 1433 & & & & \\
\hline & \multirow[t]{2}{*}{$12^{\text {th }}$ Grade } & Groups & & & & & & \\
\hline & & Total & 868,090 & 1436 & & & & \\
\hline
\end{tabular}

Source: Authors' own conception

Table 9 reveals that the needs of students for guidance differ according to their grade levels $\left(\mathrm{F}_{(3 ; 1436)}=4,606 \mathrm{p}<0.05\right)$. As a result of the oneway ANOVA performed, significant differences were identified according to the grade levels of students in their needs for educational guidance $\left(\mathrm{F}_{(3 ; 1436)}=4.935, \mathrm{p}<0.05\right)$, needs for career guidance $\left(\mathrm{F}_{(3 ; 1436)}=2.774, \mathrm{p}<0.05\right)$ and needs for personal-social guidance $\left(\mathrm{F}_{(3 ; 1436)}=4.454, \mathrm{p}<0.05\right)$. As a result of the variance homogeneity test (Levene Statistic) and LSD and Scheffe post-hoc statistics to identify the differences, it is revealed that there are significant differences in the students' need for educational guidance between the students studying at the $9^{\text {th }}$ and $10^{\text {th }}$ grades. There is also a significant difference in the students' need for career guidance between the students studying at the $11^{\text {th }}$ and $12^{\text {th }}$ grades. Significant differences are also 
identified in relation to the career guidance needs of students studying at the $11^{\text {th }}$ and $12^{\text {th }}$ grades and $9^{\text {th }}$ grade. Moreover significant differences are identified in relation to the personal-social guidance needs of students studying at the $11^{\text {th }}$ and $12^{\text {th }}$ grades between $9^{\text {th }}$ grades and $10^{\text {th }}$ grades. In later grades the needs of students for guidance increases in personal-social, educational and career development areas. Table 10 shows the distribution of the guidance needs of the students according to their grade levels.

Table 10. Distribution of the Development Area Guidance Needs of the Students According to their Grade Levels

\begin{tabular}{|c|c|c|c|c|c|}
\hline \multicolumn{2}{|r|}{ Variables } & $\begin{array}{l}\text { Personal- } \\
\text { Social } \\
\text { Guidance } \\
\text { Mean (M) }\end{array}$ & $\begin{array}{c}\text { Educational } \\
\text { Guidance } \\
\text { Mean (M) }\end{array}$ & $\begin{array}{c}\text { Career } \\
\text { Guidance } \\
\text { Mean (M) }\end{array}$ & $\begin{array}{c}\text { General } \\
\text { Mean (M) }\end{array}$ \\
\hline \multirow{5}{*}{ Grade } & $9^{\text {th }}$ Grade & 2,8797 & 3,2210 & 3,3022 & 3,0647 \\
\hline & $10^{\text {th }}$ Grade & 2,8856 & 3,3756 & 3,4008 & 3,1351 \\
\hline & $11^{\text {th }}$ Grade & 3,0498 & 3,3880 & 3,4766 & 3,2345 \\
\hline & $12^{\text {th }}$ Grade & 3,0480 & 3,4368 & 3,4885 & 3,2515 \\
\hline & Total & 2,9499 & 3,3421 & 3,4033 & 3,1568 \\
\hline
\end{tabular}

Source: Authors' own conception

Table 10 reveals that in later grades the needs of students for guidance also increases. The students state their needs in personal-social guidance area as the least, however in later grades their needs in relation to this area also increase. Moreover students' needs for guidance differ significantly according to their grade level on topics as; effective studying methods $\left(\mathrm{F}_{(3 ; 1436)}=7,648, \mathrm{p}<0.05\right)$, effective communication $\left(\mathrm{F}_{(3 ; 1436)}=6,634\right.$, $\mathrm{p}<0.05)$, coping with stress $\left(\mathrm{F}_{(3 ; 1436)}=3,470, \mathrm{p}<0.05\right)$, acquiring skills to say no when necessary $\left(\mathrm{F}_{(3 ; 1436)}=1,633, \mathrm{p}<0.05\right)$, maintaining healthy communication with the opposite sex $\left(\mathrm{F}_{(3 ; 1436)}=2,984, \quad \mathrm{p}<0.05\right)$, time management $\left(\mathrm{F}_{(3 ; 1436)}=5,604, \mathrm{p}<0.05\right)$, making effective decisions $\left(\mathrm{F}_{(3 ; 1436)}=9,528, \mathrm{p}<0.05\right)$, exam anxiety $\left(\mathrm{F}_{(3 ; 1436)}=6,488, \mathrm{p}<0.05\right)$, identifying education-related goals $\left(\mathrm{F}_{(3 ; 1436)}=3,394, \mathrm{p}<0.05\right)$, identifying career-related goals $\left(\mathrm{F}_{(3 ; 1436)}=3,081\right.$, $\mathrm{p}<0.05)$, learning how to make better use of guidance services $\left(\mathrm{F}_{(3 ; 1436)}=5,006, \quad \mathrm{p}<0.05\right), \quad$ safeguarding from negligence and abuse $\left(\mathrm{F}_{(3 ; 1436)}=3,863, \quad \mathrm{p}<0.05\right) \quad$ school regulations $\left(\mathrm{F}_{(3 ; 1436)}=3,984, \quad \mathrm{p}<0.05\right)$, professions $\left(\mathrm{F}_{(3 ; 1436)}=2.666, \mathrm{p}<0.05\right)$, opportunities for higher education $\left(\mathrm{F}_{(3 ; 1436)}=4,879, \mathrm{p}<0.05\right)$ and university admission exams $\left(\mathrm{F}_{(3 ; 1436)}=7,724\right.$, 
$\mathrm{p}<0.05)$. In this context, it can be stated that as the grade levels advance, students' needs for guidance increase.

\subsection{Findings Related to the Level of Meeting Students' Needs for Guidance}

A large majority of the stakeholders (68.3\%) from whom the qualitative data were collected within the scope of the research stated that they felt that the guidance needs of the students at the secondary education level were not met sufficiently. $29.3 \%$ of the participants stated that students' needs for guidance at this education level are partially met. Only $2.4 \%$ of the participants stated that the guidance needs of the students at this education level are met sufficiently. According to the stakeholders, there are significant problems in meeting the guidance needs of students at the secondary education level. The reasons for these problems according to the views of stakeholders are presented in Table 11.

Table 11. Reasons Why the Students' Needs for Guidance are not Sufficiently Met

\begin{tabular}{|c|c|c|}
\hline \multirow{2}{*}{ Problems } & \multicolumn{2}{|c|}{ FrequencyPercentage } \\
\hline & $(\mathrm{f})$ & $(\%)$ \\
\hline Inadequate number of school counsellors at schools & 11 & 18 \\
\hline $\begin{array}{l}\text { Too many students for each assigned school } \\
\text { counsellor }\end{array}$ & 11 & 18 \\
\hline $\begin{array}{l}\text { Practicing crisis-oriented counselling rather than } \\
\text { developmental guidance }\end{array}$ & 6 & 9,8 \\
\hline Lack of guidance hours for each level grade & 6 & 9,8 \\
\hline $\begin{array}{l}\text { The absence of necessary cooperation because the } \\
\text { administration, counsellors and parents do not have } \\
\text { sufficient guidance understanding }\end{array}$ & 6 & 9,8 \\
\hline $\begin{array}{l}\text { Teachers' lack of necessary knowledge, skills and } \\
\text { understanding regarding the guidance services }\end{array}$ & 5 & 8,2 \\
\hline $\begin{array}{l}\text { Problems with the content and implementation of the } \\
\text { activities because the class guidance programmes are } \\
\text { not updated. }\end{array}$ & 5 & 8,2 \\
\hline $\begin{array}{l}\text { Overlooking to the educational and career guidance } \\
\text { needs of students as more emphasis is given to } \\
\text { personal guidance services in schools with low } \\
\text { academic achievement such as vocational high schools }\end{array}$ & 4 & 6,6 \\
\hline The need for a more systematic model of guidance & 3 & 4,9 \\
\hline No clear identification of guidance needs & 2 & 3,3 \\
\hline
\end{tabular}


Heavy workload of school counsellors

Lack of adequate training for school counsellors at

Total

\section{Source: Authors' own conception}

Within the scope of the study, the participants mostly stated that they believe that the guidance needs of students are not sufficiently met because the number of school counsellors in schools is inadequate $(18 \%)$ and that the number of students per counsellor is too many $(18 \%)$. Moreover the participants stated that there are problems in meeting the needs of students for guidance specifically because there is a lack of guidance hours at each grade $(\% 9,8)$, the counsellors practise crisis-oriented counselling rather that developmental guidance $(\% 9,8)$, there is an absence of necessary cooperation because the administration, counsellors and parents do not have sufficient understanding of guidance $(\% 9,8)$ and there are problems with the content and implementation of the activities because the class guidance programmes are not updated $(\% 8,2)$. Furthermore the lack of clear identification of students' needs for guidance $(\% 3,3)$ is stated as one of the problems in school guidance services.

\section{Discussion}

Needs analysis is commonly defined as a way of identifying the discrepancy between the current situation and the desired situation (Gybers \& Henderson, 2012) and the process of identifying the targets that have not yet been met (Wysong, 1983). In this research which aims to identify the guidance needs of students at vocational and technical Anatolian high schools, it is revealed that the students need guidance services intensively on setting career-related future goals, learning methods of effective studying, safe internet use, learning effective communication skills, self-knowledge of interests, abilities and values, knowledge of professions and their basic requirements, focusing attention during lessons, protection from addiction, learning about developmental features of adolescence, university admission exams and opportunities for higher education.

According to the results of the study, the perceptions of the students, teachers, parents and stakeholders related to the guidance needs of the students vary. The students expressed the needs intensively for career guidance, the parents expressed the needs for educational guidance, the teachers expressed the needs most intensively for personal-social guidance and the stakeholders expressed the needs for personal-social guidance. The 
students' intensive need for career guidance services can be explained by the necessity of reconciliation of professional requirements and their personal characteristics in the process of choice of profession (Kesici, 2007). According to Super (1975), the adolescents who are at their professional discovery phase are expected to formulate their choice of profession. It can be stated that the students need guidance intensively at the point of making decisions about their careers and coping with the stress caused by this phase (Crişan et al., 2015). The reason why students and parents express their needs for personal-social guidance less than their educational and career guidance needs can be attributed to experiencing difficulties at indicating their needs on private subjects related to themselves (Çetinkaya Yıldız et al., 2018).

According to the findings obtained from the research, the guidance needs of the students vary according to their sex. Sex differentiates psychological counselling and guidance needs of girls and boys well as their physical, social and psychological aspects (Duffey \& Haberstroh, 2014; Strang, 1941). Other studies conducted also support this finding (Aydemir, 2014; Gordon, 2000; Nyutu, 2007; Valentina \& Singh, 2014). Moreover, it was concluded that female students need guidance services more than male students. This can be interpreted as a consequence in light of the decrease in gender differentiation when compared to past. Female students' need for guidance services more can be explained by their concern about their careers, fears of failing their education, greater pressure to receive better academic grades, as it requires them to make more complex decisions with reduced gender differentiation (Bishop et al., 1998).

The students studying at higher grades have more needs for guidance. In general, students in upper grades have higher expectations in terms of counselling (Wagner, 1999). As the students' grade levels rise, students' needs for guidance on learning effective methods of studying, university exams, determining career-related goals, knowledge of higher education opportunities and coping with exam anxiety also rise.

The findings of the study reveal that the guidance needs of the students at the level of secondary education are not met sufficiently. Other studies conducted at the level of secondary education (Güven, 2009; Hatunoğlu \& Hatunoğlu, 2006; Yüksel-Şahin, 2008) support this finding. It can be stated that the students' needs for guidance cannot be met sufficiently due to inadequate number of school counsellors at schools (Güven, 2009; Hatunoğlu \& Hatunoğlu, 2006; Tuzgöl-Dost \& Keklik, 2012; Yeşilyaprak, 2009), lack of guidance hours for each grade (Apaydın \& Çakır, 2016), practising crisis-oriented counselling rather than developmental 
guidance, providing counseling solely for the troubled students and not devoting enough time to the other students (Apaydın \& Çakır, 2016), the absence of necessary cooperation because the administration, counsellors and parents do not have sufficient guidance understanding (Güven, 2009; Hatunoğlu \& Hatunoğlu, 2006; Nazlı, 2007; Yeşilyaprak, 2009) and not updating the class guidance programmes and problems in the implementation of class guidance programmes (Hatunoğlu \& Hatunoğlu, 2006).

\section{Conclusion}

With this research, it is concluded that although vocational and technical Anatolian high school students need guidance services intensively in the dimensions of personal-social, educational and career development, these needs are not met at a sufficient level. In line with the findings obtained from the research, in order to meet the guidance needs of vocational and technical Anatolian high school students; it can be recommended to increase the number of school counsellors in schools, to create guidance hours for each grade during which the school counsellors can perform guidance activities and conduct activities to acquire students, counsellors and parents with an understanding of guidance. In addition, it is very important to repeat the needs analysis studies in order to meet the guidance needs of the students by preparing data-based, evidence-based, measurable, accountable school guidance programmes and identify the guidance needs of the students through different methods. In the studies of needs analysis for the guidance needs of students, it is of particular importance to develop and use competence-based, culture-sensitive tools that also take regional characteristics into consideration (Gybers \& Henderson, 2012). With the help of the measurement tools developed for this purpose, the guidance needs of the students in different school types should be evaluated at regular intervals and the psychological guidance and counselling programs should be structured according to these needs.

\section{References}

Akos, P., Cockman, C. R., \& Strickland, C. A. (2007). Differentiating classroom guidance. Professional School Counseling, 10(5), 455-463. https://doi.org/ $\underline{10.1177 / 2156759 X 0701000502}$

Altınay, F., Bastas, M., Altinay, Z., Dagli, G., \& Menemenci, N. (2020). The sustainable tool for human resources quality in educational practices. 
Identifying the Students' Needs for Guidance at Vocational and Technical ... Serdar ÖZMEN, Cigdem HURSEN

Postmodern Openings, 11(1S1), 15-32. https://doi.org/10.18662/po/11.1sup $\underline{1 / 120}$

Apaydın, S., \& Çakır, S. G. (2016). Okul yöneticilerinin psikolojik danışma ve rehberlik hizmetlerinin gerekliliği ve etkililiğine ilişkin algılarının bazı değişkenler açısından incelenmesi [An investigation of the perceptions of school managers about the need and effectiveness of psychological counseling and guidance services in terms of some variables]. In O. Demirel \& S. Dinçer (Ed.). Eğitim bilimlerinde yenilikler ve nitelik arayişi içinde [Innovations and quality in educational sciences] (pp. 655-668). Bölüm. (p.655-668). https://doi.org/10.14527/9786053183563.040

Astramovich, R. L. (2011). Needs assessment: A key evaluation tool for professional counselors. http://counselingoutfitters.com/vistas/vistas11/ Article 41.pdf

Astramovich, R. L., \& Coker, J. K. (2007). Program evaluation: The accountability bridge model for counselors. Journal of Counseling and Development, 85(2), 162172. https://doi.org/10.1002/j.1556-6678.2007.tb00459.x

Aydemir, A. (2014). 8. Sime ögrencilerinin zorba/kurban davranşlar, benlik algzlar ve rehberlik ibtiyaçlarmm değerlendirilmesi [nvestigation of 8th graders bully/victim behaviors, self-perception and guidance needs] [Unpublished master dissertation]. Gaziosmanpaşa Üniversitesi Eğitim Bilimleri Enstitüsü.

Bicen, H., \& Demir, B. (2020). A content analysis on articles using augmented reality technology and infographic in education. Postmodern Openings, 11(1S1), 33-44. https://doi.org/10.18662/po/11.1sup1/121

Bishop, J. B., Bauer, K. W., \& Becker, E. T. (1998). A survey of counseling needs of male and female college students. Journal of College Student Development, 39(2), 205-210. https://www.researchgate.net/publication/284283160

Bureš, V., \& Otčenášková, T. (2018). Complexity of information society prevents achievement of satisfactory decision making. Postmodern Openings, 9(2), 175195. https://doi.org/10.18662/po/27

Büyüköztürk, Ş., Kılıç Çakmak, E., Akgün, Ö. E., Karadeniz, Ş., \& Demirel, F. (2012). Bilimsel arasstrma yöntemleri [Scientific research methods]. Pegem Akademi Yay.

Campbell, C. A., \& Dahir, C. A. (1997). The national standards for school counseling programs. Table of Contents. The American School Counselor Association (ASCA). https://www.researchgate.net/publication/3097674 $\underline{87}$

Çetinkaya Yıldız, E., Derin, S., \& Boran, M. (2018). Ortaokul ve lise öğrencilerinin psikolojik danışma ve rehberlik ihtiyaçları [Psychological counseling and guidance needs of middle and high school students]. Mehmet Akif Ersoy 
Üniversitesi Eğitim Fakültesi Dergisi [Mehmet Akif Ersoy University Journal of Education Faculty], 47, 57-84. https://doi.org/10.21764 / maeuefd.397273

Chireshe, R. (2012). School guidance and counselling needs assessment in Zimbabwean secondary schools. The Anthropologis, 14(1), 17-24. https:// doi.org/10.1080/09720073.2012.11891215

Çoban, A. E. (2010). Mesleki rehberlik [Career guidance]. M. Güven (Ed.), Psikolojike danisma ve rebberlike [Psychological counseling and guidance] (p. 131-159). An1 Yayıncilik.

Crişan, C., Pavelea, A., \& Ghimbuluț, O. (2015). A need assessment on students' career guidance. Procedia-Social and Behavioral Sciences, 180, 1-9. https://doi. org/10.1016/i.sbspro.2015.02.196

Demirel, Ö. (2013). Eğitimde program gelistirme. Kuramdan uygulamaya [Program development in education. Theory and practice]. Pegem Yayıncilik.

Drefs, M. (2003). Developmental considerations for school-wide comprehensive guidance and counselling programs. British Journal of Guidance and Counseling, 18(4), 153-161.

Duffey, T., \& Haberstroh, S. (2014). Developmental relational counseling: applications for counseling men. Journal of Counseling \& Development, 92(1), 104-113. https://doi.org/10.1002/i.1556-6676.2014.00136.x

Erikson, E. H. (1994). Identity: Youth and crisis. W.W. Norton \& Company. New York.

Erkan, S. (2017). Psikolojik danısma ve rebberlikte program geliştirme [Program development in psychological counseling and guidance]. Pegem Yay.

Gordon, T. R. (2000). Comprehensive school programming: An assessment of adolescents' needs. [Unpublished master dissertation]. The University of Calgary, Department of Educational Psychology. http://dx.doi.org/10.11575/ PRISM/13528

Güven, S. (2009). The opinions of the ministry of national educatıon inspectors about school guidance services and supervision of these services. The Journal of International Social Research, 2(9), 171-179. https://sosyalarastir malar.com/cilt2/savi9pdf/guven mehmet.pdf

Güven, S. (2010). Okul psikolojik danışma ve rehberlik programlarının geliştirilmesi [Development of school counseling and guidance programs]. In M. Güven (Ed.), Psikolojik danisma ve rebberlik rehberlik. [Psychological counseling and guidance] (pp. 242-269). An1 Yayinc1lik.

Gybers, N. C., \& Henderson, P. (2012). Developing and managing your school guidance and counseling program (5th ed.). American Counseling Association.

Gysbers, N. C. (1997). A model comprehensive guidance program. N. Gysbers \& P. Henderson (Eds.), Comprehensive guidance programs that work II (pp. 4961). ERIC Counseling and Student Services Cleraringhouse. 
Identifying the Students' Needs for Guidance at Vocational and Technical ... Serdar ÖZMEN, Cigdem HURSEN

Gysbers, N. C. (2001). School guidance and counseling in the 21st century: Remember the past into the future. Professional School Counseling, 5(2), 96105. https://eric.ed.gov/?id=EJ655172

Hanes, M. L. (1977). An experience in program evaluation. Theory Into Practice, 16(1), 23-28. https://doi.org/10.1080/00405847709542667

Hatunoğlu, A., \& Hatunoğlu, Y. (2006). Okullarda verilen rehberlik hizmetlerinin problem alanlar1 [Problem fields of guidance services supplied in schools]. Kastamonu Eğitim Dergisi [Kastamonu Education Journal], 14(1), 333-338. https://dergipark.org.tr/tr/pub/kefdergi/issue/49106/626683

Hursen, C., \& Beyoğlu, D. (2020). The effect of geographyteaching curriculum enriched with virtual reality applications on teacher candidates' interest for the course, achievement and the tendencies to utilise information technologies. Postmodern Openings, 11(3), 73-94. https://doi.org/10.18662/ $\mathrm{po} / 11.3 / 200$

Ilgar, M. Z. (2002). Rehberliğin başlica türleri [The main types of guidance]. In G. Can (Ed.), Psikolojik danisma ve rehberlik [Psychological counseling and guidance] (pp. 25-41). Pegem Yayıncilik.

Ivlampie, I. (2018). Identity and alterity in the primitive era of globalization. Postmodern Openings, 9(2), 79-85. https://doi.org/10.18662/po/19

Kannammal, R. (2014). A study on guidance needs of urban and rural adolescence in relation to the home environment. IOSR Journal of Research and Method in Education (IOSR-JRME), 4(4), 15-27. http://www.iosrjournals.org/iosrirme/papers/Vol-4\%20Issue-4/Version-5/B04451527.pdf

Karpov, A. (2019). Ontological basis of the education phenomenon as a preformer of 1ts social and existential realities. Postmodern Openings, 10(1), 220-235. https://doi.org/10.18662/po/6

Kaya, A., \& Divitçi A. (2002). Okul psikolojik danışma ve rehberlik programlarının geliştirilmesi [Development of school counseling and guidance programs]. In G. Can (Ed.), Psikolojik danisma ve rebberlik [Psychological counseling and guidance] (pp. 201-226). Pegem Yayınc1l1k.

Kesïci, A. (2019). Eğitimde postmodern durum: Yapılandirmacılık [Postmodern situation in education: Constructivism]. Insan ve Insan [Human and Human], 6(20), 219-238. https://doi.org/10.29224/insanveinsan.442811

Kesici, Ş. (2007). Ortaöğretim öğrencilerinin anne baba tutumlarının ve rehberlik ihtiyaçlarının mesleki karar verme zorluklarını yordaması [The prediction of secondary school students 'parents' attitudes and guidance needs on vocational decision making difficulties]. Selçuk Üniversitesi Sosyal Bilimler Enstitüsü Dergisi [Selçuk University Journal of Social Sciences Institute], 18, 329-339. http://dergisosyalbil.selcuk.edu.tr/susbed/article/view/454

Korotkova, Y., Romanyuk, S., Vysochan, L., Shkleda, L., \& Kozlova, L. (2020). The phenomenon of the institution of education in the world order of 
postmodern globalization. Postmodern Openings, 11(3), 244-256. https://doi. org $/ 10.18662 / \mathrm{po} / 11.3 / 211$

Koruklu, N. Ö. (2010). Eğitsel rehberlik [Educational guidance]. In G. Can (Ed.), Psikolojik danisma ve rebberlik [Psychological counseling and guidance] (pp. 89-130). Anı Yayınclitk.

Kuzgun, Y. (2000). İlköğretimde mesleki gelişim [Career development in primary education]. In Y. Kuzgun (Ed.), Illköğretimde rebberlik. [Guidance in primary education] (pp. 125-49). Nobel Yayincll1k.

Kuzgun, Y. (2009). Rebberlik ve psikolojik danısma [Psychological counseling and guidance]. Nobel Yayınları.

Lapan, R. T. (2001). Results-based comprehensive guidance and counseling programs: A framework for planning and evaluation. Professional School Counseling, 4(4), 289-299. https:// eric.ed.gov/?id=EJ634444

Lawshe, C. H. (1975). A quantitative approach to content validity. Personnel Psychology, 28, 563-575. https://doi.org/10.1111/i.1744-6570.1975.tb0139 3.x

MacDonald, G., \& Sink, C. A. (1999). A qualitative developmental analysis of comprehensive guidance programmes in schools in the United States. British Journal of Guidance \& Counselling, 27, 415-430. http://faculty.washington. edu/gmac/pdf/DevAnalysis.pdf

Martin, J. M. (2017). The global informatin society. Routledge.

Miles, M. B., \& Huberman, A. M. (2016). Qualitative data analysis: An expanded Sourcebook. Pegem Akademi Yay.

Ministry of National Education. (2013). Milli Eğitim Bakanlı̆̆ ortaöğretim kurumlari yönetmeliği [Ministry of National Education Regulation on secondary education institutions]. https://www.mevzuat.gov.tr/mevzuat? MevzuatNo $=18812 \&$ MevzuatTur $=7 \&$ MevzuatTertip $=5$

Ministry of National Education. (2017). Milli Eğitim Bakanllğ1 rehberlik hizmetleri yönetmeliği [Ministry of National Education guidance services regulation]. http://orgm.meb.gov.tr/meb iys dosyalar/2017 11/10113305 yeni rehb rlk yon.pdf

Mitchell, B. (2016). Curriculum construction and implementation. International Journal of Liberal Arts and Social Science, 4(4). https://ijlass.org/data/ frontImages/gallery/Vol. 4 No. 4/7. 45-56.pdf

Myrick, R. D. (1989). Developmental guidance: Practical considerations. Elementary School Guidance and Counseling, 24(1), 14-30. https://www.jstor. org/stable/42868885

Nazlı, S. (2005). Kapsaml gelisimsel rebberlike ve psikolojik danısma programlar [Comprehensive developmental guidance and psychological counseling programs]. Anı Yayıncll1k. 
Nazlı, S. (2007). Okul yöneticilerinin rehberlik ve psikolojik danışma hizmetlerini alg1lamalar1 [School principals' perception of the guidance and counseling service]. Eurasian Journal of Educational Research, 26, 155-166. https://hdl. handle.net $/ 20.500 .12462 / 5156$

Nazlı, S. (2014). Polis Akademisi kapsamlı gelişimsel rehberlik programının orta vadeli değerlendirilmesi [Medium-term evaluation of Police Academy comprehensive developmental guidance program]. https://dergipark.org.

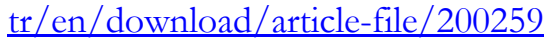

Negi, K. (2017). Educational and psychological guidance needs of college students. Imperial Journal of Interdisciplinary Research (IJIR), 3(1), 1672-1677. http:// www.onlinejournal.in/IJIRV3I1/295.pdf

Nyutu P. N. (2007). The development of the student counseling needs scale (SCNS). [Unpublished doctoral dissertation]. The Faculty of Graduate School University of Missouri-Columbia. https://core.ac.uk/download/pdf/6276 1674.pdf

Oliva, P. F. (2005). Developing the curriculum (6 th $^{\text {th }}$ ed.). Pearson/Allyn and Bacon.

Prabu, S. (2015). A study on guidance needs among higher secondary students. IOSR Journal of Humanities \& Social Science, 20(7). https://doi.org/10.9790/ $\underline{0837-20771417}$

Robinson, J. E. (1999). Comprehensive needs assessment project for elementary school students. [Unpublished master dissertation]. The University of Calgary, Department of Educational Psychology.

Strang, R. (1941). Do girls need guidance? The Journal of Education, 124(1), 15-17. https://doi.org/10.1177/002205744112400108

Super, D. E. (1975). Career education and career guidance for the life span and for life roles. Journal of Career Education, 2(2), 27-42. https://doi.org/10. $1177 / 089484537500200204$

Tamir Tetroashvili, L., \& Mezan, R. (2020). Innovation management in family health clinics in Israel: The contribution of customer needs' assessment. Postmodern Openings, 11(1), 149-161. https://doi.org/10.18662/po/112

Tan, H. (1995). Psikolojik danısma ve rebberlik [Psychological counseling and guidance]. MEB Yayınları.

Tuzgöl Dost, M., \& Keklik İ. (2012). Alanda çalışanların gözünden psikolojik danışma ve rehberlik alanının sorunları [Professional issues in counseling as perceived by individuals working in counseling settings]. Mehmet Akif Ersoy Üniversitesi Eğitim Fakültesi Dergisi [Mehmet Akif Ersoy University Journal of Education Faculty], 23, 389-407. https://dergipark.org.tr/tr/download/ article-file/181388

Valentina, L., \& Singh R. (2014). Gender differences in guidance needs of senior secondary school adolescents of imphal district. International Journal of 
Educational Sciences, 6(3), 521-524. https://doi.org/10.1080/09751122.2014. 11890163

Wagner, N. S. (1998). A comparison of adult and traditionally-aged students' expectations about counseling. [Unpublished doctoral dissertation]. Department of Psychology the Ohio State University.

Wysong, E. H. (1983). Needs assessment in counseling, guidance, and personnel services. Searchlight plus: Relevantresources in high interest areas. Eric Counseling and Personnel Services Clearınghouse. https://files.eric.ed.gov/fulltext/ED23 9190.pdf

Yeşilyaprak, B. (2009). The development of the field of psychological counseling and guidance in Turkey: Recent advances and future prospects Ankara University, Journal of Faculty of Educational Sciences, 42(1), 193-213. https://doi. org/10.1501/Egifak 0000001144

Yeşilyaprak, B. (2019). 21. Yüzylda eğitimde rebberlike bizmetleri-gelisimsel yaklaşım [Counseling services in education in the 21st century-developmental approach] (28nd ed.). Nobel Yay.

Yüksel-Şahin, F. (2008). Ortaöğretimdeki öğrenci görüşlerine göre psikolojik danışma ve rehberlik hizmetlerinin değerlendirilmesi [Evaluation of school counseling and guidance services based on views of high school students]. Uluslararasi Insan Bilimleri Dergisi [International Journal of Human Sciences], 5(2), 1-26. https://www.j-humansciences.com/ojs/index.php/IJHS/article $\angle$ view/491 